\title{
A Literature Review of Issues and Tasks by Period of Revision of Regulations Related to Convalescent Rehabilitation Wards in Japan: Focusing on Quality Evaluation
}

\author{
Minyoung Lee', Boyoung Jeon ${ }^{2}$
}

'Department of Healthcare and Public Health Research, National Rehabilitation Research Institute, Seoul, Republic of Korea; ${ }^{2}$ Department of Health and Medical Information, Myongji College, Seoul, Republic of Korea

Purpose: Japan established the convalescent rehabilitation wards, corresponding to Korea's rehabilitation medical institutions, in 2000 and developed it into the present system through continuous revisions. This study sought to analyze the issues and tasks faced by Japan segregated by the period of revision of convalescent rehabilitation ward-related medical fee regulations, through a literature review and further aimed to explore the direction of development of domestic rehabilitation medical institutions.

Methods: Ten revisions of the medical fee regulations were classified into three stages based on quality evaluation: (1) the quantitative expansion stage (2000-2006); (2) quality evaluation introduction stage (2008-2014); and (3) quality evaluation maturity stage (20162020).

Results: The following issues and tasks emerged: (1) For the quantitative expansion stage; insufficient rehabilitation within the ward, insufficient after-hour rehabilitation, insufficient connection with acute-stage hospitals and maintenance facilities, and the low ratio of specialists. (2) For the quality evaluation introduction stage; disparity in the manpower between institutions, the necessity of a 365-day rehabilitation system, avoidance of critical patients, and the problem that an increase in the amount of rehabilitation did not lead to a qualitative improvement. 3) For the quality evaluation maturity stage; cream-skimming issues in selecting patients, inappropriate evaluation of rehabilitation effects, and the necessity of follow-up measures after discharge.

Conclusion: It is worth referring to the established regulations in Japan, and concurrently it is necessary to strengthen the evaluation of the structures, processes, and results when operating and evaluating rehabilitation medical institutions in Korea taking into account the side effects that could be identified in Japan.

Keywords: Community care, Convalescent rehabilitation ward, Rehabilitation medical institute, Return to home, Quality evaluation

서 론

우리나라 고령화율은 2021년 현재 16.5\% 이상으로, 2025년에는 65세 이상 인구가 총 인구의 $20 \%$ 이상에 달하는 초고령사회로 진입할 것 으로 전망된다.1 정부는 노인인구 증가에 따른 입원기간 장기화, 의료 비 증가, 재활난민 발생 등의 문제를 해결하기 위한 방편 중 하나로 아급성기, 혹은 회복기 재활을 강화하고자 2019년부터 재활의료기 관을 지정하기 시작하였다. 재활의료기관은 발병 또는 수술 후 기능 회복이 가능한 일정기간 동안 집중적인 재활치료를 통해 일상생활 활동(activities of daily living, DL)을 향상시킴으로써 조기에 사회 복귀 할 수 있도록 재활의료 전달체계를 개선하기 위하여 신설된 제도로, 흔히 '회복기재활병원’ 이라고도 불린다. 회복기는 집중적인 재활치
료를 통해 단기간에 높은 재활효과를 볼 수 있는 단계로 적극적인 재 활역량 발휘가 필요한 시기인 만큼 물리·작업·언어치료 등 재활전문 직 종사자들이 재활의료기관에 대해 많은 관심을 가지고 실효성 있 는 제도로 성장할 수 있도록 연구하고 의견을 제시할 필요가 있을 것 으로 사료된다.

병원 기반 회복기 재활을 제도화한 해외 선행사례로 영미권의 집 중재활입원시설(inpatient rehabilitation facility)과 일본의 회복기재활 병동(回復期リハビリテーション病棟) 등이 있다. 특히, 일본은 2000년 에 고령화율이 이미 $17.3 \%$ 에 달하여 병상수가주요국 가운데 가장 높 았고, 와상상태의 장기입원환자가 점차 늘어나는 가운데 개호보험제 도(한국의 (장기요양보험제도) 시행과 함께 회복기재활병동 제도를 신설하였다.5 제도 도입 초기에는 영미권의 집중재활입원시설을 벤치
Received Jan 17, 2022 Revised Feb 21, 2022

Accepted Feb 25, 2022

Corresponding author Minyoung Lee

E-mail wharen88@gmail.com
Copylight ( 2022 The Korean Society of Physical Therapy

This is an Open Access article distribute under the terms of the Creative Commons Attribution Non-commercial License (https:// creativecommons.org/license/by-nc/4.0.) which permits unrestricted non-commercial use, distribution, and reproduction in any medium, provided the original work is properly cited. 
마킹하였으나 시행 이후 현재까지 20년간 격년에 한번, 총 10 회에 걸 친 진료보수 규정 개정을 통해 일본의 독자적인 제도로 정착시켰다. ${ }^{5}$ 진료보수 규정에서 정의하는 회복기재활병동은 "뇌혈관 질환 또는 대퇴골 경부 골절 등의 환자에 대해 $\mathrm{ADL}$ 을 향상시킴으로써 와상상 태 방지와 재택복귀를 목적으로 한 재활을 집중적으로 실시하기 위 한 병동이며, 회복기 재활을 필요로 하는 상태의 환자의 입원을 항시 $80 \%$ 이상 유지하는 병동”으로 질환에 따라 60 일부터 180 일까지 입 원 가능하다. 회복기재활병동 입원료는 진료보수 중 특정 입원료에 해당하여 포괄수가제를 채택하고 있다. 현행 회복기재활병동은 시설 의 인력배치 및 진료실적 등의 기준을 조합하여 그 수준별로 시설을 입원료1-6의 6가지 단계로 세분화하고, 각 단계별로 지불하는 입원료 에 차등하는 두는 방식으로 질평가를 수행하고 있다. ${ }^{5}$ 일본 자국 내 에서 회복기재활병동 제도에 대한 평가는 도입 초기인 2001년 75개이 었던 병동수가 2020년에는 15.3 배 증가한 1,145 개에 이르는 양적 팽창 과 더불어 2008년 질평가 도입, 2016년 결과평가 도입 등을 통해 질적 개선이 이루어졌고, 재원일수, 재택복귀율, 일상생활기능 개선도가 향상된 것으로 보고되고 있어 그 효과성을 인정받고 있다.56

우리나라는 건강보험수가 등 의료제도에 있어 상대적으로 일본과 유사성이 높아 재활의료기관 설계 시 일본의 회복기재활병동을 일 부 참조하였다. 예를 들어, 입원대상 질환군, 질환별 입원기간, 수가 체계 등은 일본의 제도와 유사하며, 인력기준, 시설 및 장비기준, 환 자구성비 등은 아직 제도 시행 초기라는 점을 감안하여 기관 지정을 위한 필수요건 이외에는 구간별 배점을 통해 점수에 차등을 두는 방 식으로 유연하게 적용하고 있다. 현재까지는 총 45 개 병원이 재활의 료기관으로 지정 받은 것에 그치고 있으나 향후 본 제도의 양적 팽창 및 질적 개선과 더불어 한국의 실정에 맞는 제도로 발전시키기 위한 노력이 필요하다.

한편, 재활의료기관은 우리나라 독자적으로 개발된 제도가 아닌 국외 선진사례를 벤치마킹하여 설계된 것이다 보니 아직 보건의료 종사자들조차 시설의 설립 목적과 기능 및 역할 등 제도에 대한 이해 도가 높지 않은 실정이다. 특히, 재활전문직 종사자들은 본 제도를 직 접 이행할 주체로써 제도에 대한 이해도를 높여 효과적이면서도 국 내 실정에 맞는 제도 운영방안 마련을 위한 연구와 정책 제안에 적극 적으로 임할 필요가 있다. 일본의 회복기재활병동제도는 재활의료기 관 설계 시 벤치마킹한 사례 중 하나로 우리보다 20년에 앞서 시행착 오와 검증을 거쳐 현재의 제도로 정착하였다. 이에, 일본의 회복기재 활병동 제도의 내용을 파악하고, 그 발전과정에서 대두된 쟁점과 과 제를 살펴보는 것은 재활전문직 종사자들이 재활의료기관 설립의 목적과 그 기능을 이해하고, 제도 수행과정에 따를 수 있는 위험요소 들을 미리 예견하여 이에 대한 대안을 마련하는 폭넓은 시야를 갖추 는데 도움을 줄수 있을 것으로 사료된다.
본 연구에서는 일본 회복기재활병동 관련 진료보수 규정의 시기 별 개정내용과 시기별로 대두되었던 주요 쟁점 및 과제를 살펴보고 자 한다. 특히, 2000년에 제도를 도입한 이후 2006년 개정에서 최초로 질평가가 도입되었고, 2016년 개정에서 결과평가가 도입되었다는 일 본 정부의 자체적인 평가에 따라 전체 개정 변천사를 질평가를 중심 으로 1) 양적 팽창기, 2) 질평가 도입기, 3) 질평가 성숙기의 3 단계 시기 로 구분하여 살펴보고자 한다.

\section{연구 방법}

\section{1. 연구설계}

본 연구는 일본에서 회복기재활병동이 신설된 2000년부터 현재까지 의 회복기재활병동 관련 진료보수 규정의 시기별 개정내용과 주요 쟁점 및 과제를 Kingdon'의 다중흐름모형에서 제시하는 주요 구성요 소별로 나누어 후향적으로 분석하였다. 다중흐름모형은 정책의제가 이슈화되고 결정되는 과정을 다양한 흐름들 간의 관계 속에서 분석 하여 각 변수들의 상호작용에 따라 정책형성 과정이 어떻게 변화하 는지에 대한 이해의 틀을 제공한다. ${ }^{89}$ 본 모델은 다음 6 가지 구성요소 를 통해 정책형성 과정을 설명한다. 1) 정책문제의 흐름(policy problem stream')은 잠재된 문제들이 특정한 조건을 만나 표출될 때 정부 및 정책결정자가 이것을 문제로 인지하는 과정이다. 2) '정치의 흐름 (political stream)'은 국가적 분위기, 이념의 변동, 행정부의 교체, 이익 집단의 압력 등이다. 3) '정책대안의 흐름(policy alternative stream)'은 연구자 및 이해관계 집단 등 정책참여자들에 의한 대안의 구체화 과 정이다. 4) '정책선도자(policy entrepreneur)'는 정책대안의 흐름 중 선 호하는 대안을 제시하고 그것이 정책의 창을 통과하며 정책 산출이 이루어지도록 돕는다. 5) '정책의 창(policy window)'은 정치와 정책문 제의 흐름 속에 떠다니던 정책대안이 연결되어 정책 결정의 기회가 오는 것을 의미한다. 6) '정책산출(policy outputs)'은 법률의 제정 및 개 정, 정책결정 등에 해당한다. ${ }^{8}$

진료보수 규정은 격년마다 개정되도록 되어 있어 주기적 개정이 곧 '정책의 창'으로 기능한다. 또한 개정과정에서 후생노동성이 위촉 한 중앙사회보험의료협의회(이하 '중의회') 회의를 여러차례 개최하 여 정책이슈를 발제하고 논의한 후 개정의 기본방침을 정하여 후생 노동성에 제시하면 후생노동성이 그 결과를 발표하므로 중의회가 '정책선도자'로서의 역할을 수행한다고 보았다. 이에, 본 연구에서는 '정책문제의 흐름, '정치의 흐름, '정책대안의 흐름' '정책산출'을 주요 분석대상으로 하였다. '정책문제의 흐름, '정치의 흐름, '정책대안의 흐 름의 결합은 '정책산출'에 이르기까지의 상황을 제시함으로써 언제, 왜, 어떻게 정책결정이 이루어지는지에 대한 분석의 틀을 제공한 다.10,11 


\section{2. 자료분석}

본 연구에서는 '정책산출로 후생노동성이 발표한 정부보고서를 통 해 진료보수 규정 개정내용을 수집. 분석하였다. 정책문제의 흐름과 '정책대안의 흐름'은 회복기재활병동의 현황과 과제, 문제점, 정책제 안 등의 내용을 다룬 일본 국내 발표 논문, 좌담회 보고서, 심포지엄 발제문 등의 문헌자료와 당시 보도된 신문기사 또는 인터넷기사를 통해 파악하였다. '정치의 흐름'은 정부에서 발표한 정책 방향, 회복기 재활병동과 관련된 타 법제도 신설, 이해관계 집단의 출현 등으로 파 악하였다. 상기 일본어 자료들은 주저자가 번역하여 분석하는 과정 을 거쳤다. 일본 독자적인 제도명은 직역하되 해당 단어가 최초 출현 시 괄호안에 일본명을 기술하고, 동일한 의미를 가진 한글명이 있는 경우 괄호 안에 한글명도 함께 기술하였다.

총 10 회의 개정 시기를 질평가를 중심으로 다음의 3 가지 시기로 구 분하고, 각 시기별로 '주요 정책산출', '정치의 흐름, '정책문제 및 정책 대안의 흐름을 분석하였다. 1) 양적 팽창기: 2000-2006년 개정, 2) 질평 가 도입기: 2008-2014년 개정, 3) 질평가 성숙기: 2016-2020년 개정. 단 2004년 에는 회복기재활병동에 특화된 진료보수 규정 개정이 이루 어지지 않아 분석대상에서 제외하였다.

\section{결 과}

회복기재활병동 관련 시기별 주요 진료보수 규정 개정내용은 Table 1 과같다.

\section{1. 양적 팽창기: 2000 2006년 개정}

1) 주요 정책산출

(1) 2000년도 개정

회복기 재활을 필요로 하는 환자, 즉 뇌혈관질환 및 척수손상, 대퇴골 경부골절, 하지 및 골반골절, 외과수술 및 폐렴 등의 치료로 인해 발 생한 폐용증후군(廃用症候群, 한국의 '비사용증후군')을 보이는 발 병 혹은 수술 후 3 개월 이내의 환자를 대상으로 가능한 조기에 집중 적인 재활을 수행함으로써 $\mathrm{ADL}$ 을 향상시켜 재활복귀를 촉진하는 역할을 수행하는 회복기재활병동을 신설하고 회복기재활병동 입원 료를 진료보수체계 상 포괄수가제를 적용하는 특정 입원료로 지정 하여 질환과 상관없이 최대 180 일까지 입원료를 산정 가능하도록 하 였다. 평가는 구조설비와 인력배치 등에 따른 시설기준과, 복잡(40 분). 간단(15분) 등 치료시간을 기준으로 한 기존의 의료체계를 따르 되, 치료실이 아닌 병동 내에서의 재활에 중점을 두고 재활종합실시 계획서 작성 등 팀 어프로치를 평가한다는 것에 특징이 있다. 병동 전 종(專從) 의사 1 명, 물리치료사 2 명, 작업치료사 1 명 이상을 필수 인력 배치 요건으로 하였다. '전종이란 병동 내 재활 업무 이외에 다른 업
무는 겸임할 수 없는 근무형태를 의미한다.

\section{(2) 2002년도 개정}

복잡(40분) ·간단(15분) 등 치료시간 중심 평가체제를 폐지하고 개별 치료 및 집단치료로 구분하였다. 치료시간 20 분을 1 단위로 하여 환자 1 명당 1 일 최대 6 단위(2시간)까지 산정 가능하도록 하였다. 병동ADL 가산(病棟ADL加算) 제도를 신설하여 “입원 중인 환자에게 병동 등 에서 조기 보행, $\mathrm{ADL}$ 자립 등을 목적으로 물리치료를 수행한 경우” 해당 환자에 대하여 1 단위 당 가산점을 부여하였다.

\section{(3) 2006년도 개정5}

개별치료 평가를 환자의 질환에 맞추어 수행하자는 취지에서 포괄 수가로 지급되는 회복기재활병동 입원료 이외에 4 가지 질환별재활 료(e.g., 뇌혈관질환, 운동기, 호흡기, 심대혈관질환)를 신설하고 질환 별로 차별화된 입원료 산정 일수 상한을 설정하였다. 1 일 산정 가능 한 최대 재활치료 단위수를 6단위(2시간)에서 9단위(3시간)로 변경하 였다. 병동ADL가산제도를 개편하여 “훈련실 이외 옥외를 포함한 병 동에서" “자립을 목적으로 실용보행훈련, 일상생활훈련을 실시한 경 우”에 가산한다고 하여 훈련실을 제외한다는 내용을 구체적으로 명 시하였다. 병동 입원기준을 발병일 이후 3 개월 이내에서 2 개월 이내 로 변경하여 조기 재활을 유도하였다. 대퇴골경부골절 환자에 대하 여 지역연계진료계획관리료 및 지역연계진료계획퇴원시지도료를 신설하였다.

\section{2) 정치의 흐름}

정부는 2000 년 진료보수 개정에 있어 중의회의 기본방침을 발표하여 의료기관을 급성기, 회복기, 유지기로 구분하여 각 기능을 분담하고, 끓임없는 의료연계구축을 위하여 지역연계를 촉진하자는 관점을 제 시하였다. ${ }^{5}$ 이에, 급성기재활은 가능한 조기에 종료하고 회복기, 유지 기재활에 충실을 기할 수 있도록 함으로써 질환의 중증화와 장기화 를 막고자 회복기재활병동을 신설하고 재택의료를 지속적으로 강화 하였다. 한편으로 사회적 부담으로 작용하는 노인 돌봄문제를 국가 적 차원에서 해결하고자 개호보험제도를 창설하여 유지기에 수행되 는 통소재활(通所リハビリテーション, 한국의 '데이케어')과 방문재활 (在宅リハビリテーション)을 포함한 각종 서비스들을 사회보험 적용 대상으로 전환시킴으로써 서비스 양을 비약적으로 증가시켰다. ${ }^{4}$ 2001년에는 회복기재활병동협회가 설립되어 매해 회복기재활병동의 운영 현황을 분석하고, 분석결과를 근거로 진료보수 개정 방향에 대 한 입장을 발표함으로써 중의회의 기본방침 결정에 압력을 가하기 시작하였다. ${ }^{12}$ 
Table 1. Major revisions of medical fee regulations related to the Convalescent Rehabilitation Ward

\begin{tabular}{|c|c|c|}
\hline Stage & $\begin{array}{l}\text { Revision } \\
\text { year }\end{array}$ & Major revisions \\
\hline \multirow[t]{7}{*}{ Quantitative expansion stage } & 2000 & Establishment of hospitalization fee for Conversant Rehabilitation Ward \\
\hline & 2002 & Evaluation criteria changed from 'complex (40 minutes)'/simple (15 minutes)' to 'individual'/group' \\
\hline & & $\begin{array}{l}\text { Setup } 20 \text { minutes of rehabilitation training as } 1 \text { unit, and maximum payable rehabilitation training as } 6 \text { units per } \\
\text { person per day }\end{array}$ \\
\hline & & Establishment of additional points for activities of daily living training in the ward ( 2008) \\
\hline & 2006 & Establishment of rehabilitation fee by the type of disease \\
\hline & & Setup the maximum payable hospitalization days for each of types of disease \\
\hline & & Change of maximum payable rehabilitation training from 6 units to 9 units per person per day \\
\hline \multirow[t]{11}{*}{ Quality evaluation introduction stage } & 2008 & $\begin{array}{l}\text { Classification of hospitalization fee } 1 \text { and } 2 \text { considering the rate of return to home and the proportion of severely } \\
\text { ill patients }\end{array}$ \\
\hline & & $\begin{array}{l}\text { Establishment of additional points for the ward with more than } 30 \% \text { of patients with improved activities of daily } \\
\text { living upon discharge among severely ill patients (for hospitalization fee } 1 \text { ) }\end{array}$ \\
\hline & & Establishment of additional points for early rehabilitation from the time of hospitalization to 30 days \\
\hline & 2010 & Establishment of mandatory regulation for performing rehabilitation training 2 or more units per person per day \\
\hline & & Establishment additional points for rehabilitation training more than 6 units per person per day ( 2018) \\
\hline & & Establishment additional points for ward equipped with a system that allows holiday rehabilitation \\
\hline & 2012 & $\begin{array}{l}\text { Classification of hospitalization fee } 1 \text { to } 3 \text { considering the manpower, the rate of return to home and the } \\
\text { proportion of severely ill patients }\end{array}$ \\
\hline & & Establishment of additional points for early rehabilitation within 14 days and 15 to 30 days after onset \\
\hline & 2014 & Establishment of mandatory regulation for establishing holiday rehabilitation system (for hospitalization fee 1) \\
\hline & & $\begin{array}{l}\text { Establishment of additional points for the ward strengthening the rehabilitation system as employing } 1 \text { full-time } \\
\text { doctor and } 1 \text { full-time social worker (for hospitalization fee 1) }\end{array}$ \\
\hline & & $\begin{array}{l}\text { Establishment of additional points for visiting patient's home and instructing home-based rehabilitation during } \\
\text { hospitalization }\end{array}$ \\
\hline \multirow[t]{6}{*}{ Quality evaluationmaturity stage } & 2016 & Introduction of the rehabilitation performance index \\
\hline & 2018 & Classification of hospitalization fee 1 to 6 by combination of basic part and performance part \\
\hline & & $\begin{array}{l}\text { Application of medical insurance for outpatient rehabilitation and visiting rehabilitation in convalescent } \\
\text { rehabilitation ward }\end{array}$ \\
\hline & & Expansion of facilities subject to patient's return to home \\
\hline & 2020 & Upward adjustment of the rehabilitation performance index for hospitalization fee 1,3 , and 5 \\
\hline & & Establishment of mandatory regulation on the explanation about the rehabilitation plan to the patient \\
\hline
\end{tabular}

\section{3) 정책문제 및 정책대안의 흐름}

이 시기 회복기재활병동 수는 도입 초기인 2001년과 비교하였을 때 2007년에 7배 이상 증가하는 등 회복기재활병동의 급격한 양적 팽창 을 보여주고 있다. ${ }^{6}$ 임상 및 학계는 전반적으로 회복기재활병동 도입 이 병원재원일수와 발병일로부터 재활개시일까지의 기간을 단축하 고 자택복귀율 개선하는 등 긍정적인 효과가 있었다고 평가하였 다. ${ }^{13,14}$ 또한, 병동 내에서의 $\mathrm{ADL}$ 개선의 중요성과 팀 어프로치에 대한 인식개선이 있었다는 점에서 긍정적이라는 의견이 있었다. ${ }^{14}$ 한편, 병 원 간 재활서비스 질의 양극단화 현상을 포함한 다음과 같은 문제점 과 과제들이 도출되었다.

\section{(1) 병동내 재활 미흡}

일본재활의학회에서 2001년 398개 병원 대상으로 수행한 설문결과 에 따르면 재활치료실이 아닌 병동내에서의 일상생활기능 회복을 위
한 취지와는 달리 '병동 내에서' 재활이 이루어진다고 답한 경우는 물 리, 작업, 언어치료에서 각각 $39 \%, 42 \%, 32 \%$ 에 그쳤다. ${ }^{13}$ 국립보건의료 과학원 Inoue 등 ${ }^{15}$ 이 2001년에 99개 병원을 대상으로 수행한 또다른 설문결과에서도 물리치료사와 작업치료사의 '병동 내에서의 업무는 $30 \%$ 를 조금 넘는 수준으로 나타나 병동 내 훈련이 미흡함을 알 수 있 다. 또한 병동 전종 물리치료사 2 명, 작업치료사 1 명 등의 인력배치 법 정기준을 그대로 이행하고 있는 시설이 $60 \%$ 를 넘는 반면, 재활전문인 력을 10 명 넘게 배치하여 인력을 강화한 병동도 존재하는 등 병동 간 인력배치 양상에 큰 격차를 보였다. ${ }^{15}$ 후생노동성은 이에 대한 대안책 으로 2002년 개정에서 병동ADL가산 제도를 신설함으로써 병동 내 재활을 독려하였다. ${ }^{5}$

\section{(2) 시간외 재활체계 미흡}

Inoue 등 ${ }^{15}$ 의 연구에 따르면 물리치료사, 작업치료사가 조조, 야간, 일 
요일 휴일 등 시간외 재활서비스를 수행하는 경우는 $10 \%$ 이하인 것 으로 나타났다. 회복기재활병동협회에서 조사한 2001-2007년 시간외 재활 실시현황에서도 물리·작업·언어치료 모두 토요일은 $70 \%$ 이상 의 높은 실시율을 보였으나, 일요일과 휴일재활은 $50 \%$ 이하의 저조한 실시율을 보였고, 조조 및 야간 재활을 제공하는 곳은 $30 \%$ 에도 미치 지 못했다. ${ }^{6}$ 한 좌담회 보고서에 따르면 365 일 재활서비스체제를 유 지하는 병원이 있는가 하면 일요일과 휴일은 재활을 아예 수행하지 않는 병원도 존재하는 것으로 나타났고, 조조, 야간재활을 잘 수행하 고 있는 병원도 일부 존재하는 반면, 대부분의 병원에서는 수행하고 있는 않은 등 시간외 재활에 대한 병원 간 격차가 크다고 하였다. ${ }^{16}$ 후 생노동성은 이에 대한 대안책으로 2010년 개정에서 휴일재활제공체 제가산(休日リハビリテーション提供体制加算) 제도를 신설하여 휴일 재활이 가능한 체제를 갖추고 있는지를 평가하였다. 구체적인 내용 은 질평가 도입기의 주요 정책산출에서 후술하였다.

\section{(3) 급성기 병원 및 유지기 시설 연계 미흡}

몇몇 연구에서 회복기재활병동의 급성기 병원과의 연계, 퇴원 후 재 택시스템과 유지기 시설과의 연계가 미흡한 것을 문제점으로 지적하 였다.14,17 2005 년 일본재활의학회 심포지엄에서 회복기재활병동제도 도입 초기에는 가택복귀 이후에 방문재활로 이어지리라는 기대가 있 었으나 실제 저자가 소속된 병원에서 방문재활로 이어지는 사례는 $10 \%$ 에 불과한 등 퇴원 후 후속조치 실시체제가 아직 갖추어 지지 못 했다는 보고가 있었다. ${ }^{17}$ 한편, 2007년 12개 도도부현 347개 병원을 대 상으로 조사한 결과에 따르면, '타원의 회복기병동과의 연계가 양호 한지에 대한 물음'에 '양호하다'가 $42 \%$ 이었고, 실제 지역패스 등으로 의료정보를 공유하고 있는 병원은 $13 \%$ 에 불과하였다. ${ }^{18}$ 후생노동성 은 이에 대한 대안책으로 2006년 개정에서 대퇴골경부골절 환자에 대하여 지역연계진료계획관리료 및 지역연계진료계획퇴원시지도료 를 신설하여 지역연계 critical path 활성화를 독려하고, 2008년 개정에 서는 그 대상 질환을 뇌졸중에까지 확대하였다. ${ }^{5}$

\section{(4) 전종 재활의학과 전문의 비율 저조}

일본재활의학회 심포지엄에서 회복기재활병동의 전종의가 대부분 재활의학과 전문의가 아닌 것을 문제점으로 지적하고, 회복기재활병 동의 질을 개선하기 위해서는 전종 의사로 재활의학과 전문의가 바 람직하다는 의견을 제시하였다. ${ }^{1719}$ 후생노동성은 이에 대한 대안책 으로 2012년 개정에서 입원료 1 에 대하여는 재활의학과 의사 1 명의 배치를 필수요건으로 하였다. 구체적인 내용은 질평가 도입기의 주요 정책산출에서 후술하였다. ${ }^{5}$

\section{2. 질평가 도입기: 2008 2014년 개정}

\section{1) 주요 정책산출 \\ (1) 2008년도 개정5}

재택복귀율 및 중증환자 입원 비율을 기준으로 입원료 1,2 를 구분하 는 방식으로 질평가를 도입하였다. 더 엄격한 요건을 갖추어야 하는 입원료 1 의 경우 병동에 회복기재활을 필요로 하는 환자를 $80 \%$ 이상 입원하도록 하고, 신규 입원환자 중 $15 \%$ 이상이 중증환자이면서 퇴 원환자 중 타 보험의료기관에 전원한 자 등을 제외한 환자, 즉 재택복 귀 환자의 비율이 $60 \%$ 이상이어야 한다고 규정하였다. 입원료 1 병동 에 한하여 중증환자회복병동가산(重症患者回復病棟加算) 제도를 신설하여 중증환자 중 퇴원 시 ADL이 개선된 환자가 $30 \%$ 이상인 경 우 가산점을 부여하였다. 조기재활가산(早期リハビリテーション加算) 제도를 신설하여 질환별재활료 산정일수 상한의 기산일부터 30 일 간에 한하여 가산점을 부여하였다. 인력배치와 관련하여 기존에 ‘병 동 전종 의사 1 명 이상'에서 '전임(專任) 의사 1 명 이상’으로 규정을 변 경하여 의사의 배치조건을 완화하였다. '전임'이란 불가피한 경우 병 동 내 재활 업무 이외에 다른 업무, 예를 들어 외래 진료, 방문진료 등 을 겸임할 수 있는 근무형태를 의미한다. 지역연계진료계획관리료 및 지역연계진료계획퇴원시지도료를 뇌졸중 환자에게 확대 적용하였다.

\section{(2) 2010년도 개정5}

입원료 1 산정요건 중 신규 입원환자 중 중증환자의 비율을 $15 \%$ 이상 에서 $20 \%$ 이상으로 상향 조정하였다. 모든 입원환자에 대해서 1 일 1 인당 2 단위 $(40$ 분) 이상의 재활치료를 필수로 규정하였다. 재활충실가 산(1)ハビリテーション充実加算) 제도를 신설하여 1 일 1 인당 6 단위(2 시간) 이상 시행한 경우 가산점을 부여하였다. 휴일재활제공체제가 산(休日リハビリテーション提供体制加算) 제도를 신설하여 휴일을 포함한 모든 날에 재활치료를 수행할 수 있도록상근 혹은 비상근 물 리치료사 또는 작업치료사 1 명을 병동에 배치하고 휴일에도 1 인당 평 균 2 단위 정도의 재활치료를 수행하는 등 평일과 현저히 다르지 않은 재활제공체제를 갖추고 있는 경우 가산점을 부여하였다.

\section{(3) 2012년도 개정5}

입원료를 3 단계로 개편하고 입원료 1 에 대해서 인력배치 요건 강화 및 재택복귀율, 중증환자입원비율 상향 조정 등 평가기준을 강화하 였다. 입원료 1 산정을 위해 전임 재활의학과 의사 1 명, 전종 물리치료 사 3 명 이상, 작업치료사 2 명 이상, 언어청각사 1 명 이상, 전임 사회복 지사 등 1 명 이상, 간호사 배치 상시 13:1, 간호보조사 배치 상시 30:1 등 의 인력배치와 재택복귀율 $70 \%$ 이상, 신규 입원환자 중 중증환자 $30 \%$ 이상, 중증환자 중 $30 \%$ 이상이 일상생활기능이 개선될 것 등을 요건 으로 하였다. 초기재활가산(初期リハビリテーション加算) 제도를 신 
설하여 발병 후 14 일 이내와 발병 후 15 일 이상 30 일 이내에 입원한 경 우로 구분하여 차별화된 가산점을 부여하였다.

\section{(4) 2014년도 개정}

입원료 1 의 경우 휴일재활제공체제를 가산점 부여요건이 아닌 입원 료 산정요건으로 변경하였다. 체제강화가산(体制強化加算) 제도를 신설하여 병동에 전종 의사 1 명 이상 및 전종 사회복지사 1 명 이상이 배치되었을 경우 가산점을 부여하였다. 이때 전종 의사는 재활의료 관련 3년 이상 경력을 가지고 적절한 재활 관련 연수(14시간 정도)를 수행해야하는 것으로 규정하였다. 입원시방문지도가산(入院時訪問 指導加算) 제도를 신설하여 의사, 간호사, 물리치사, 작업치료사 또는 언어치료사 중 최소한 1 명 이상이 필요에 따라 사회복지사, 간호지원 전문원, 개호복지사 등과 협력하여 환자의 자택 등에 방문하여 퇴원 후의 거주환경 등을 평가하고 재활종합실시계획을 작성한 경우 가 산점을 부여하였다. 재활계획제공료, 재활종합계획평가료, 퇴원시재 활지도료를 신설하였다.

\section{2) 정치의 흐름}

일본 정부는 2014년 의료개호일괄법에서 '병상기능 보고제도를 창설 하여, 병상구분을 고도급성기, 급성기, 회복기, 만성기로 설정하고, 일 본의 단카이 세대가 모두 75세 이상이 되는 2025년에 맞추어 각 도도 부현에서 목표로 삼아야할 의료제공체계의 모습을 '지역의료구상' (地域医療構想) 이라는 이름으로 계획하도록 하였다. ${ }^{20} 2013$ 년 지역 포괄케어시스템(地域包括ケアシステム, 한국의 '지역사회통합돌봄시 스템')의 법적 정의가 처음으로 도입되었고, ${ }^{21} 2014$ 년에는 진료보수 규 정에 지역포괄케어병동입원료가 신설되었다. 2013 년 기존에 존재하 던 재활 관련 5 개 단체연락협의회(일본재활의학회, 일본재활병원·시 설협회, 일본물리치료사협회, 일본작업치료사협회, 일본언어치료사 협회의)에 3 개 단체(일본방문재활협회, 회복기재활병동협회, 전국노 인데이케어연락협의회)가 새롭게 합류하여 '전국재활의료관련단체 협의회'를 발족하여 중의회의 기본방침에 압력을 가하기 시작하였 다. ${ }^{22}$

\section{3) 정책문제 및 정책대안의 흐름}

이 시기에는 회복기재활병동 수가 지속적으로 증가하는 가운데 병 원 간 인력 및 재활강도 격차문제가 대두되었고, 이를 개선하기 위해 2008년에 처음으로 질평가를 도입하여 재택복귀율, 중증환자 비율 에 따라 입원료에 차등을 두기 시작하였다. 또한 발병 후 빠른 시일 내에 높은 강도의 재활을 제공하도록 하기 위하여 조기재활가산, 재 활충실가산, 휴일재활제공체제가산, 초기재활가산을 신설하였다. ${ }^{5}$ 그러나 질평가 도입으로 병원이 중증환자 입원을 기피하는 부작용
에 대한 우려의 목소리가 있었고, 각종 제도가 신설되어 재활양이 증 가했음에도 불구하고 질적 개선으로 이어지지 않는다는 비판의견도 제기되었다.

\section{(1) 의료기관 간 인력배치 격차 문제}

회복기재활병동협회는 2008년 진료보수 개정으로 도입된 질평가가 Donabedian ${ }^{23}$ 이 제시한 의료서비스 질평가의 3 가지 요소인 구조, 과 정, 결과 중 결과 측면의 평가라고 판단하고, 결과지표 뿐만 아니라 프 로세스와 구조 지표를 병용하여 평가해야 할 필요성을 언급하였 다.24,25 결과지표로 중증환자 입원 비율을 평가하고자 하나 중증환자 재활에 필요한 간호사나 재활전문 인력이 부족한 상황에서 중증환 자에게 적절한 재활양을 제공할 수 없어 결과적으로 환자의 $\mathrm{ADL}$ 저 하로 이어질 수 있다는 것이다.24,25 협회에서 2008년 536개 병원을 대 상으로 조사한 결과에 따르면 병원당 평균 재활전문인력 수는 물리 치료사 4.6 명, 작업치료사 3.4 명, 언어치료사 0.9 명이었는데, 규정대로 물리치료사 2 명, 작업치료사 1 명으로만 운영하고 있는 병동이 $52.4 \%$ 로 반수 이상을 차지하고 있어, 인력 강화에 힘쓰는 병원과 기준 내에 서만 운영하고 있는 병원 간의 격차가 확대되고 있는 경향이 있었 다. ${ }^{26}$ 협회는 이에 대한 대안으로 2006년 개정에서 입원료 1 에 대해서 인력요건을 '전임 의사 1 명 이상'으로 완화했던 것을 '전종 의사 1 명 이 상으로 부활시키고, 전종 물리치료사와 작업치료사를 현행 요건보 다 1 명씩 더 늘리는 등의 방안을 제시하였다. ${ }^{25}$ 후생노동성은 이와 같 은 요구를 일부 받아들여 2012년 개정에서 입원료 1 에 대하여 전종 물리치료사 3 명, 작업치료사 2 명 이상으로 인력요건을 강화하였다. ${ }^{5}$

\section{(2) 365 일 재활체제 구축을 통한 재활강도 강화 필요} 2006년부터 1 일 평균 9단위까지 재활제공이 가능해짐에 따라 조조, 야간, 토/일요일, 휴일 재활을 수행하는 병원이 서서히 늘어나는 추세 이기는 하나, ${ }^{26}$ 협회가 2008 년 조사에 따르면 여전히 약 $70 \%$ 의 병동에 서 365 일, 24 시간의 재활제공이 실시되지 않고 있으며, 재활 단위수는 평균 4.5 단위이나 재활 단위수가 4 단위 이하인 병동이 $40 \%$ 이상 존 재하는 것으로 나타나 의료기간 간 재활양의 격차가 큰 것이 판명되 었다. ${ }^{25}$ 조사결과를 바탕으로 협회는 환자 1 인당 1 일 6 단위 이상의 재 활을 365 일 실시할 수 있는 체제를 갖춘 경우 가산점을 부여하는 방 안을 제안하였다. ${ }^{25}$ 이에 후생노동성은 2010년 개정에서 휴일을 포함 한 모든 날에 평균 2단위 정도의 재활치료를 수행할 수 있는 재활제 공체제를 갖춘 경우 휴일재활제공체제가산을 부여하도록 하였다. ${ }^{5}$

\section{(3) 질평가 도입에 따른 중증환자 기피 문제}

2008년 개정에서 입원료 1 산정요건을 신규 입원환자 중 중증환자 $15 \%$ 이상, 재택복귀율 $60 \%$ 이상으로 하고 있고, 퇴원 시 $\mathrm{ADL}$ 개선 환 
자가 $30 \%$ 이상인 경우 가산점을 부여하고 있으나, 이 같은 요건 하에 서는 중증환자를 $15 \%$ 보다 높은 비율로 입원시키는 경우에도 재택복 귀율 60\% 이상을 맞춰야 하고, 퇴원 시 $\mathrm{ADL}$ 개선도까지 높아야 하기 때문에 병원 입장에서는 수익을 올리기 위하여 중증환자를 기피하 는 현상이 발생할 수 있다는 문제점이 제기되었다. ${ }^{27}$ 이에, 중증환자 비율이 일정수준 이상으로 높은 경우 재택복귀율 기준을 낮춰주거 나, 중증환자회복병동가산 제도를 폐지하는 등의 방편이 대안책으 로 제시되었다.25,27

\section{(4) 재활량 증가가 질적 개선으로 이어지지 않는 문제}

2010 년에 재활치료 1 인당 1 일 2 단위 이상 수행 필수 규정이 신설되고, 재활충실가산과 휴일재활제공체제가산 제도가 도입되어 환자 1 인당 질환별 재활의 평균 실적단위수는 증가한데 비하여 재활효과는 이 에 미치지 못하고 의료기관 간의 재활의 질 격차가 크다는 지적이 있 었다. ${ }^{28} 2006$ 년부터 2014년까지의 추이를 보면 환자 1 인당 질환별 재활 의 평균 재활실시 단위수는 2006년에 3.74단위에서, 2014년에 5.80단 위로 8 년간 1.55 배 증가하였으나, 퇴원 및 입원 시 수행하는 일상생활 동작검사(Functional Independent Measure, FIM) 점수의 차이는 이 기 간 내내 16-17점을 유지하여 거의 변화하지 않았다. ${ }^{28}$ 이에 후생노동 성은 2016년 개정에서 재활효과와 재원일수를 동시에 고려한 재활실 적지수를 도입하여 재활의 효율성을 평가하기 시작하였다. 구체적 인 내용은 질평가 성숙기의 주요 정책산출에서 후술하였다.

\section{3. 질평가 성숙기: 2016 2020년 개정}

1) 주요 정책산출

(1) 2016년도 개정5

재활치료의 질과 입원기간의 적정화를 위하여 재활실적지수를 이용 한 결과평가를 적용하였다. 재활실적지수의 조작적 정의는 환자의 퇴원 시와 입원 시 FIM 운동항목의 차이인 'FIM 이득을 환자의 실제 재원일수를 입원료 산정 상한일수로 나눈 결과로 다시 나누는 것으 로, 결과적으로 FIM 이득이 크고, 재원일수가 짧을수록 실적지수는 높은 값을 갖는다. 이는 실적지수가 일정수준에 미달하는 의료기관 에 대해서는 질환별재활료를 6 단위까지만 인정함으로써, 6 단위를 넘 는 질환별재활료에 대한 재정지원을 제한할 뿐 아니라 사실상 재활 충실가산도 제한하는 엄격한 규제이다. 기존의 체제강화가산 제도에 추가로 체제강화가산 ${ }^{2}$ 제도를 신설하여 전종의사 2 명은 특정일, 특정 시간에 한해서 외래 진료, 방문재활 등 입원 외의 진료도 수행할 수 있도록 함으로써 환자가 회복기재활병동을 퇴원한 후에도 재활의 연 결성이 담보될 수 있는 환경을 조성하였다.

\section{(2) 2018년도 개정5}

질평가를 개편하여 (1) '기본적인 의료평가 부분'과, (2) '진료실적에 대 응한 단계적 평가 부분'을 조합하여 입원료를 6단계로 세분하였다. '기본적인 의료평가 부분'에서는 인력배치, 재활실적지수의 원내 개 시, 데이터 제출, 휴일재활 제공(입원료 1.2에 한함) 등을 평가하고, '진 료실적에 대응한 단계적 평가 부분에서는 중증환자 입원 비율, 중중 환자 퇴원 시 $\mathrm{ADL}$ 개선 정도, 재택복귀율, 재활실적지수 등을 평가하 였다. 이때, 입원료 $1,3,5$ 에는 재활실적지수를 적용하는 반면, 입원료 $2,4,6$ 에는 적용하지 않았다. 회복기재활병동의 외래 및 방문재활이 의료보험의 적용을 받도록 개편하였다. 재택복귀율 산정 대상 시설 로 인정하던 자택, 특별양호노인홈(特別養護老人ホーム), 거택계시 설등(居住系介護施設等), 양호노인홈(養護老人ホーム) 외에 돌봄서 비스를 제공하는 유상진료소(有床診療所), 개호의료원(介護医療 院) 등을 포함시켜 재택복귀 범위를 넓혔다.

\section{(3) 2020년도 개정5}

재활실적 개선에 대한 질 보장 방편으로 진료보수 규정에 "입원 후 2 주 이내에 입원 시 FIM 운동항목 득점결과와 퇴원 시 목표로 하는 FIM 운동항목 점수를 재활실행계획서를 이용하여 환자에게 설명하 고, 요구가 있으면 교부하여야 한다”고 규정하였다. 입원기준 중 “발병 일로부터의 2 개월 이내'라는 기간요건을 폐지하였다. 2020년도에 최 종적으로 발표된 회복기재활병동 입원료 체계는 Figure 1과 같다.

\section{2) 정치의 흐름}

후생노동성은 2016년 진료보수 개정의 기본방침으로 효과적·효율적 이고 질 높은 의료 시행과, 효율화. 적정화를 통해 제도의 지속 가능 성 향상을 제시하여 의료의 효율성을 강조하기 시작하였다. 2018 년 은 개정주기가 3 년인 개호보험법과 개정주기가 2년인 진료보수 규정 의 개정시기가 맞물리는 시점으로 급성기, 회복기, 유지기 모든 단계 의 입원료 체계를 '기본적인 평가' 와 '진료 실적에 따른 평가'의 두가 지 요소를 조합하여 세분화하는 방식으로 대폭 개편하였다. ${ }^{5}$

\section{3) 정책문제 및 정책대안의 흐름}

일본 정부에서 2016년 결과평가 도입 후의 상황을 조사. 분석한 결과 평균재원일수 단축, 재택복귀율 향상, 중증환자의 입원율 향상 등의 성과가 있었다고 평가하였다. ${ }^{29}$ 그러나 이해관계 단체들은 결과평가 도입에 따르는 부작용에 대해 우려의 목소리를 내기도 하였는데, 실 적지수를 높이기 위하여 애초에 높은 개선을 기대할 수 있는 환자만 을 선별하여 입원시킨다거나, ${ }^{30,31}$ 입원 시점의 실적지수를 인위적으 로 낮게 조작함으로써 FIM 이득을 높이는 행위들을 부작용의 예로 들었다. ${ }^{30}$ 이에 대한 대안책으로 제 3 자 평가 등의 의견이 제시되었다.32 


\begin{tabular}{|c|c|c|c|c|c|c|}
\hline & $\begin{array}{l}\text { Hospitalization } \\
\text { fee } 1\end{array}$ & $\begin{array}{l}\text { Hospitalization } \\
\text { fee } 2\end{array}$ & $\begin{array}{l}\text { Hospitalization } \\
\text { fee } 3\end{array}$ & $\begin{array}{l}\text { Hospitalization } \\
\text { fee } 4\end{array}$ & $\begin{array}{l}\text { Hospitalization } \\
\text { fee } 5\end{array}$ & $\begin{array}{l}\text { Hospitalization } \\
\text { fee } 6\end{array}$ \\
\hline doctor & \multicolumn{6}{|c|}{1 or more full-time employees ${ }^{9}$} \\
\hline Nursing staff* & \multicolumn{2}{|c|}{$\begin{array}{c}13 \text { to } 1 \text { or more } \\
\text { ( } 70 \% \text { or more are nurses) }\end{array}$} & \multicolumn{4}{|c|}{15 to 1 or more ( $40 \%$ or more are nurses) } \\
\hline Nursing assistant ${ }^{+}$ & \multicolumn{6}{|c|}{30 to 1 or more } \\
\hline Rehabilitation professionals & \multicolumn{2}{|c|}{$\begin{array}{c}\text { Full-time PT } 3 \text { or more, OT } 2 \text { or } \\
\text { more, ST } 1 \text { or more }\end{array}$} & \multicolumn{4}{|c|}{ Full-time PT 2 or more, OT 1 or more } \\
\hline Social worker & \multicolumn{2}{|c|}{ Full-time 1 or more " } & \multicolumn{4}{|c|}{-} \\
\hline Registered dietitian & Full-time 1 & \multicolumn{5}{|c|}{ It is desirable to have 1 full-time employee } \\
\hline $\begin{array}{l}\text { Description of nutrition items } \\
\text { in the rehabilitation plan }\end{array}$ & Mandatory & \multicolumn{5}{|c|}{ If a registered dietitian is assigned: desirable to do } \\
\hline $\begin{array}{l}\text { Disclosure of rehabilitation } \\
\text { performance index by posting } \\
\text { in the hospital }\end{array}$ & \multicolumn{6}{|c|}{ O } \\
\hline $\begin{array}{l}\text { Notification of additional } \\
\text { points for data submission }\end{array}$ & \multicolumn{4}{|c|}{ O } & \multicolumn{2}{|c|}{$O(※$ There is a transitional measure) $"$} \\
\hline Holiday rehabilitation & \multicolumn{2}{|c|}{ 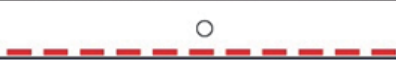 } & \multicolumn{4}{|c|}{ (※There is additional points for ward equipped with a system that allows holiday rehabilitation) } \\
\hline $\begin{array}{l}\text { Percentage of } \\
\text { severely ill patient }\end{array}$ & \multicolumn{2}{|c|}{$30 \%$ or more } & \multicolumn{2}{|c|}{$20 \%$ or more } & \multicolumn{2}{|c|}{-} \\
\hline $\begin{array}{l}\text { Evaluation of daily living } \\
\text { vfunctions at discharge in } \\
\text { severely ill patients } \$ \\
\text { ※ () Indicates total FIM score }\end{array}$ & \multicolumn{2}{|c|}{$\begin{array}{l}30 \% \text { or more improved by } 4 \text { points } \\
\text { ( } 16 \text { points) or more }\end{array}$} & \multicolumn{2}{|c|}{$\begin{array}{l}30 \% \text { or more improved by } 3 \text { points } \\
\text { (12 points) or more }\end{array}$} & \multicolumn{2}{|c|}{-} \\
\hline $\begin{array}{l}\text { Percentage of discharge to } \\
\text { home, etc. }\end{array}$ & \multicolumn{4}{|c|}{$70 \%$ or more } & \multicolumn{2}{|c|}{-} \\
\hline $\begin{array}{l}\text { Rehabilitation performance } \\
\text { index } \|\end{array}$ & 40 or more & - & 35 or more & - & 30 or more & - \\
\hline$=-2-2=-2$ & 2,129 points & 2,066 points & 1,899 points & $\overline{1,841 \text { points }}$ & 1,736 points & 1,678 points \\
\hline
\end{tabular}

Figure 1. Current Convalescent Rehabilitation Ward hospitalization fee system announced in the 2020 medical fee revision. *Nursing staff includes health nurses, midwives, nurses, and associate nurses. ${ }^{+}$Nursing assistant is a job that mainly takes care of patients and supports nurses. No national qualifications required. FSeverely ill patients mean a person with a Barthel Index 10 points or more or a Functional Independent Measure total score of 55 points or less at the time of hospitalization. ${ }^{\circledR} \mathrm{A}$ daily living function measures using a Barthel Index and Functional Independent Measure. "Rehabilitation performance index=Difference in Functional Independent Measure exericse item scores between discharge and hospitalization/ (Length of hospital stay/The maximum payable hospitalization days for each of types of disease). "In case of doctor and social worker, full-time means a state in which one can perform other jobs in case of unavoidable circumstances that do not interfere with original job. ${ }^{* *} A$ preparation period of 4 to 5 months is allowed for data submission in the hospital system and preparation for data preparation, etc. Note. referenced from overview of the revision of medical fees in 2020, Ministry of Health, Labor and Welfare.

또한, 유지기 재활로의 매끄러운 연착륙을 위해 회복기재활병동 퇴 원 후 후속조치의 필요성이 대두되었다. ${ }^{33}$

(1) 입원환자에 대한 cream skimming 문제

실적지수 도입으로 FIM 이득이 클 것으로 예상되는 환자를 선별하는, 소위 cream skimming의 가능성이 있다는 의견이 제시되었다. ${ }^{30} \mathrm{FIM}$ 평 가의 객관성을 담보하기 위하여 동영상 등을 이용하여 환자에게 제 공한 재활의 내용을 교차 분석함으로써 cream skimming의 유무를 판정할 수 있다는 의견을 제시되었다. ${ }^{31}$ 한편, cream skimming을 근본 적으로 피하기 어렵다면 재활을 통해 단기간에 개선을 기대하기 힘 들어 병원에서 선호하지 않는 환자의 입원을 위해서 입원료 $2,4,6$ 에 서는 실적지수를 도입하지 않을 것을 제안하는 의견이 제기되었다. ${ }^{31}$
후생노동성은 이와 같은 요구를 받아들여 2018년 개정에서 입원료 $2,4,6$ 에서는 실적지수를 도입하지 않았다. ${ }^{5}$

(2) 부적절한 재활실적지수 평가 문제

협의회의 조사결과에 따르면 재활실적지수를 입원료 평가에 반영한 2016년도 이후 FIM 이득이 커졌다. ${ }^{30}$ 이와 같은 결과에 대해 각 병원 이 조기에 집중적인 재활을 실시함에 따른 것이라고 평가하는 의견 이 있는 반면, 발병부터 입원까지의 기간은 2007년 즈음부터 감소하 고 있으나 당시에는 FIM 이득에 변화가 없다가 2016년부터 퇴원 시 FIM 점수에는 변함이 없이, 입원 시 FIM 점수만 저하되고 그것이 결 과적으로 FIM 이득의 증가로 연결되고 있는 사실로 미루어 입원 시 FIM 점수를 인위적으로 조작하여 FIM 이득을 높이고 있는 것이라 
는 의심을 제기하는 의견이 있었다. ${ }^{30}$ 후생노동성은 이와 같은 FIM 이 득 평가 조작 위험에 대한 대안책으로 2020년도 진료보수 개정에서 입원 시 FIM 평가결과와 퇴원 시 FIM 목표 점수 등을 재활실행계획 서를 이용하여 환자에게 설명하도록 하는 조치를 도입하여 $\mathrm{ADL}$ 평 가에 대한 적정성을 담보하고자 하였으나,5 2020 년도 개정 후에도 입 원 시 FIM 점수가 지속적으로 감소하고 있어 여전히 문제점으로 남 아있었다. ${ }^{34}$ 한편, 2021 년 전국재활의료관련단체협의회는 의료기능 평가기구의 병원기능평가인정을 받은 회복기재활병원과 받지 않은 병원을 비교했을 때, 2020년도 개정 전후 입원 시 FIM 저하율이 비인 정병원에서는 크고(7\%), 인정병원에서는 작게 나타나는 사실로 미루 어(2\%), 비인정병원에서 입원 시 FIM 점수에 대한 부적절한 조작이 더 크게 있었을 가능성을 제기하였다.32 이에 최소한 입원료 1 병동에 대해서는 병원기능평가 등의 제 3 자 평가를 프로세스 평가로 도입하 는 방안을 제안하였다. ${ }^{5}$

(3) 퇴원 후 후속조치 평가 및 재택의료 지원체제 강화 필요

후생노동성 진료보수조사 전문조직이 조사한 바에 따르면 퇴원 후 방문재활과 외래재활을 받은 군은 퇴원 후 1 개월 후에도 $\mathrm{ADL}$ 저하 가 보이지 않은 반면, 그렇지 않은 군은 $\mathrm{ADL}$ 이 저하되었다고 하였 다. ${ }^{33}$ 회복기재활병동 퇴원 후에도 $60 \%$ 의 환자는 재활훈련이 필요한 상태이고, 회복기재활병동을 신고한 의료기관 중 $72 \%$ 는 방문재활을, $65 \%$ 는 외래재활을 실시하고 있어 회복기재활병동의 퇴원 후 후속조 치 실시체제가 강화되었다는 데이터를 제시하면서 퇴원 후 일정기간 재활 제공 시 가산점을 부여하는 제도의 필요성을 제기하였다. ${ }^{33}$ 또 한, 회복기재활병동에서 퇴원 후 환자에게 재활을 제공하기 쉬운 환 경을 구축하기 위하여 병동 전종 재활 전문직이 외래와 재택에서의 재활 제공 등 병동 외 업무를 일정 정도 수행할 수 있도록 하는 등 유 연하게 대처할 수 있는 체제를 구축할 필요가 있다고 하였다. ${ }^{33}$ 후생 노동성은 이와 같은 요구를 받아들여 2016년 개정에서 체제강화가 산2 제도를 신설하여 전종의사 2 명은 특정일, 특정시간에 한해서 입 원 외의 진료도 수행할 수 있도록 하고, 2018년 개정에서 회복기재활 병동 재활 전문직의 외래 및 방문재활에 대해 의료보험을 적용하는 조치를 취하였다. ${ }^{5}$

\section{고 찰}

20 년간의 총 10 회의에 걸친 진료보수 규정 개정은 2008 년 질평가 도 입과, 2016년 결과평가 도입으로 양적 팽창에서 질적 수준 향상과 효 율성 개선으로 성장하는 과정이었고, 이 과정을 통해 환자들의 재원 기간 단축, 재택복귀율, 중증환자 입원 비율, $\mathrm{ADL}$ 개선도 향상 등의 긍정적인 결과가 있었으나 한편으로는 시기별로 주목할 필요가 있는
부작용들도 발생하였음을 알수 있다.

양적 팽창기는 일반병원과 요양병원들이 회복기재활병동으로 쉽 게 유입될 수 있도록 입원료 산정요건을 지나치게 엄격하게 규제하지 않으면서 일본의 상황에 맞는 회복기재활병동 평가기준들을 정립해 나가는 과정이었다. 이 시기에는 제도가 도입된 지 얼마 지나지 않은 데서 비롯된 병동 내 재활에 대한 인식 부족, 재활량 부족, 인력배치 미흡 등이 문제가 대두되었다. 질평가 도입기에는 두가지 특징적인 정 책산출 방향을 확인할 수 있는데, 첫째는 질평가를 위하여 재택복귀 율과 중증환자 입원 비율과 같은 결과 지표를 도입한 것이고, 둘째는 조기 집중재활을 유도하기 위하여 조기재활가산, 초기재활가산, 휴 일재활제공체제가산, 체제강화가산 등의 구조 및 프로세스 지표들 을 신설한 것이다. 이와 같은 조치들로 인해 병동의 질적 수준이 향상 되고, 재활량이 늘어나는 효과가 있었으나, 동시에 질평가 도입에 따 른 중증환자 기피 문제, 재활량 증가가 질적 개선으로 이어지지 않는 문제 등의 부작용도 나타났다. 질평가 성숙기에는 전 시기에 각종 가 산 제도들로 대처해오던 구조 및 프로세스 지표들을 입원료 산정을 위한 평가의 한 축인 '기본적인 의료평가 부분'에 편입시킴으로써 구 조 및 프로세스 평가를 강화한 것으로 해석할 수 있다. 또한, 효율성 개선을 위하여 보다 짧은 재원기간 동안 높은 $\mathrm{ADL}$ 개선을 이끌어 내 도록 유도하기 위하여 재활실적지수라는 결과평가를 도입하였다. 그 결과 점차적으로 보다 짧은 기간 동안 높은 $\mathrm{ADL}$ 개선도를 보이는 효 율성 향상을 보였으나, 동시에 입원환자에 대한 cream skimming 문 제, 부적절한 재활실적지수 평가 문제 등의 부작용이 발생하여 성과 제일주의라는 비판도 제기되었다.

우리나라 재활의료기관 지정 및 지정을 위한 평가는 『장애인 건강 권 및 의료접근성 보장에 관한 법률 시행령』(장애인건강권법 시행 령') $)^{35}$ 과 동법 시행규칙(장애인건강권법 시행규칙') ${ }^{36}$ 에서 규정하고 있고, 세부적인 평가 방법 및 절차는 『재활의료기관 지정 및 운영 등 에 관한 고시에서 규정하고 있다. ${ }^{2}$ 고시 제 3 장에서는 재활의료기관 의 지정과 관련하여 평가대상 기간, 인력, 시설, 장비, 환자구성, 진료 량, 회복기재활환자 구성 비율 등 주로 구조 측면에서의 기준을 규정 하고 있고, 인력, 진료량, 회복기재활환자 구성 비율은 구간별로 배점 을 차별화하는 형식으로 점수에 차등을 둠으로써 구조를 강화한 의 료기관일수록 많은 점수를 획득하도록 하여 사실상 일본의 가산점 제도와 유사한 평가방법을 취하고 있다. ${ }^{2}$ 이후 재활의료기관에 프로 세스 및 결과평가 도입 시 일본의 사례에서 효과가 검증된 규정들은 참조하되, 부작용들도 감안하여 결과 뿐 아니라 구조 및 프로세스 평 가를 함께 강화시켜 나갈 필요성이 있을 것으로 사료된다.

진료보수 규정의 개정과정에서 '다중흐름모형'의 '정책의 창'과 '정 책선도자로 기능하는 제도적 장치들이 마련되어 있었던 것은 회복 기재활병동 제도가 현장의 목소리를 민감하게 포착하여 담아내는 
살아있는 제도로 성장하는데 중요한 환경적 요소로 작용한 것으로 사료된다. 시대에 따른 사회적 변동이나 경제상황에 부응하기 위하 여 일본의 진료보수 규정 개정 주기는 2년으로 규정되어 있는데, 이것 이 곧 '정책의 창'으로써 기능하고 있었다. 또한, 후생노동성이 위촉한 중의회는 매 개정 시기마다 여러 차례의 회의를 거쳐 정책이슈를 발 제하고 논의하여 개정의 기본방침을 정하는 '정책선도자'의 역할을 수행하고 있었다. 이와 같은 제도적 장치 하에 이해관계 단체와 학자 및 임상가들은 중의회가 개정 시마다 발표하는 개정의 기본방침에 영향력을 행사하고자 각종 현황 조사, 기자 회견, 좌담회 및 심포지엄 개최, 논문 발표 등 다양한 매체들을 동원하여 문제점과 대안책들을 제시하였고, 중의회는 이와 같은 의견들을 개정의 기본방침에 적극 적으로 반영해왔다. 우리나라 재활의료기관 평가 방법 및 절차를 규 정하는 『재활의료기관 지정 및 운영 등에 관한 고시 ${ }^{2}$ 에는 개정 주기 에 대해 규정된 바가 없다. 이에, 재활의료기관이 시대적 상황과 현장 의 목소리를 반영하는 살아있는 제도로 운영될 수 있도록 보건복지 부는 개정 주기와 개정까지의 과정을 이끌어갈 정책선도자의 역할 을 수행할 기구 혹은 위원회를 규정할 필요가 있고, 정책선도자는 개 정과정을 국민이 납득할 수 있도록 근거에 기반하여 투명하게 운영 할 필요가 있다.

일본 진료보수 규정은 급성기, 회복기, 유지기의 기능분화와 각 기 능 간의 유기적인 연계를 기본적인 기조로 하여 진화해왔고, ${ }^{5}$ 회복기 재활병동의 발전과정은 보건의료 및 복지체계의 전반적인 발전과정 과 맞물려 있다. 예를 들어 2013년에는 지역포괄케어시스템 ${ }^{20}$ 이 처음 으로 법으로 규정된 이후 유지기에 해당되는 지역포괄케어병동, 개 호의료원 등 새로운 시설들이 등장함에 따라 회복기재활병동 퇴원 환자의 재택복귀 대상 시설 정의도 확대 개편되었다. 또한, 회복기재 활병동을 신고한 의료기관 중 외래재활과 방문재활을 함께 운영하 는 기관의 비율이 점차 늘어남에 따라, 2018년부터는 이 같은 의료행 위에 대해서도 의료보험이 적용되도록 진료보수 규정을 개정하였다. 보건복지부는 2018년에 지역사회 통합돌봄('커뮤니티케어') 기본계 획을 발표하고,37 2019년에 16 개 지방자체단체를 선정하여 지난 2년간 선도사업을 추진하였다. ${ }^{38}$ 보건복지부가 정의하는 지역사회 통합돌 봄이란, 노인, 장애인 등이 평소 살던 곳에서 살아갈 수 있도록 주거. 보건의료·요양·돌봄 등을 통합적으로 제공받는 지역주도형 사회서 비스 정책이다. ${ }^{37}$ 환자가 조금이라도 빨리, 안정적으로 살던 곳으로 복귀하기 위해서는 회복기 단계에서 조기에 집중적인 재활훈련을 받 을 필요가 있고, 퇴원 시점에는 유지기 시설 들과의 원활한 연계를 통 해 지역사회에 안착하는 과정이 필요하다. 이에 향후 재활의료기관 제도의 발전 방향은 급성기, 회복기, 유지기를 포괄하는 지역사회 통 합돌봄차원에서 모색될 필요가 있다.

일본의 회복기재활병동 관련 진료보수 규정 개정과정은 2008년
질평가 도입과, 2016년 결과평가 도입으로 양적 팽창에서 질적 수준 향상과 효율성 개선으로 성장하는 과정이었다. 이 과정을 통해 환자 들의 재원기간 단축, 재택복귀율, $\mathrm{ADL}$ 개선도 향상 등 긍정적인 결과 가 검증되었으나, 중증환자 기피 문제, $\mathrm{ADL}$ 평가 결과 조작 등 성과 제 일주의에 따르는 부작용도 발생하였음을 알 수 있었다. 이는, 향후 우 리나라에서 재활의료기관에 질평가를 적용함에 있어 일본의 선험 적 사례에서 효과가 검증된 규정들은 참조하여 반영하되, 부작용들 을 고려하여 결과평가 뿐 아니라 구조 및 프로세스 평가도 함께 강화 해 나가야할 필요성이 있음을 시사한다. 본 연구는 우리나라의 재활 의료기관 제도 도입 초기에 관련 데이터와 연구가 부족한 상태에서 일본 회복기재활병동 제도의 선험적 발전과정을 확인함으로써 우리 나라 재활의료기관 제도의 발전방향을 모색하는데 기여할 수 있을 것으로 사료된다.

\section{ACKNOWLEDGEMENTS}

이 논문은 2019년 대한민국 교육부와 한국연구재단의 지원을 받아 수행된 연구임(NRF-2019S1A5C2A03081040).

\section{REFERENCES}

1. Statistics Korea. 2021 senior citizen statistics [Internet]. South Korea: 2021 Sep 29 [cited 2021 Dec 28]. Available from: https://www.kostat. go.kr/portal/korea/kor_nw/1/1/index.board?bmode=read\&aSeq $=403253$.

2. Ministry Health and Welfare. Notification on the designation and operation of rehabilitation medical institutions [Internet]. South Korea: 2019 Aug 30 [cited 2021 Dec 28]. Available from: http://www.mohw.go.kr/react/jb/sjb0406vw.jsp?PAR_MENU_ID=03\&MENU_ID=030406\& CONT_SEQ=350647.

3. Ministry Health and Welfare. Notification of evaluation plan related to $\ulcorner$ 1st Rehabilitation Medical Institution Designation」 [Internet]. South Korea: 2019 Aug 29 [cited 2021 Dec 28]. Available from: https://www. mohw.go.kr/react/al/sal0301vw.jsp?PAR_MENU_ID=04\&MENU_ ID=0403\&CONT_SEQ=350645.

4. Ministry of Health, Labor and Welfare. The long-term care act [Internet]. Japan: 2021 Apr 1 [cited 2021 Dec 28]. Available from: https:/elaws. e-gov.go.jp/document?lawid=409AC0000000123.

5. Ministry of Health, Labor and Welfare. Overview of the revision of medical fees [Internet]. Japan: 2021 Dec 28 [cited 2021 Dec 28]. Available from: www.mhlw.go.jp/stf/seisakunitsuite/bunya/0000106602. html.

6. Kaifukuki Rehabilitation Ward Association. Survey report on the current status and issues of convalescent rehabilitation ward. Tokyo, Kaifukuki Rehabilitation Ward Association, 2021:5-166.

7. Health Insurance Review and Assessment Service. Evaluation of rehabilitation medical institution designation and operation pilot project and performance evaluation and compensation system development [Inter- 
net]. South Korea: 2018 Dec 27 [cited 2021 Dec 28]. Available from: https://www.hira.or.kr/rc/icenter/study/getReportInfo.do?pgmid= HIRAA030095000000.

8. Kingdon JW. Agendas, alternatives, and public policies. Boston Little, Brown and Company, 1984:1-273.

9. Jin SH, Park JH. A comparative study on the energy policies of South Korea and Germany: focusing on policy stream model. The Korean Association for Policy Stuides. 2012;21(3):265-89.

10. Mannheimer LN, Lehto J, Östlin P. Window of opportunity for intersectoral health policy in Sweden-open, half-open or half-shut? Health Promot Int. 2007;22(4):307-15.

11. Lee YR, Choi SK, Kim IS et al. Study on reorganization of service and qualification management between nurse and nurse assistant: focusing on policy stream model by kingdon. Health and Social Welfare Review. 2018;38(1):489-519.

12. Kaifukuki Rehabilitation Ward Association. About the kaifukuki rehabilitation ward association [Internet]. Japan: 2001 Feb 1 [cited 2021 Dec 28]. Available from: www.rehabili.jp/organization/index.html.

13. Oshima S, Honda T, Ishida A. Current status and subjects of convalescent rehabilitation ward. JARM. 2002;39(7):359-61.

14. Kurosawa T. Current status and problems of convalescent rehabilitation ward. JARM. 2002;39(1):s124.

15. Inoue Y, Kake A. Consideration on the actual condition of the convalescent rehabilitation ward from a national survey: a study on the ideal state of the convalescent rehabilitation ward. Architectural Institute of Japan Planning Papers. 2003;68(571):55-61.

16. Ito T, Okamochi T, Koizumi K et al. Roundtable discussion: thinking about the convalescent rehabilitation ward. Saitama Physical Therapy. 2005;12(1):2-10.

17. Sonoda S, Nagai S, Saito S. Current status and issues of convalescent rehabilitation wards: merits and demerits of convalescent rehabilitation ward. JARM. 2005;42(9):609-36.

18. Koga N, Uehara T, Nagatsuka K et al. National questionnaire survey to understand the current situation of stroke community medicine: current status of hospitalization facilities during the maintenance period. J Stroke. 2008;30(5):710-22.

19. Ikenaga Y, Nomura T. Current status and issues of convalescent rehabilitation wards: reexamination of indications for convalescent rehabilitation wards. JARM. 2005;42(9):609-36.

20. Ministry of Health, Labor and Welfare. The act of totally reservation of medical care and nursing care [Internet]. Japan: 2021 Oct 1 [cited 2021 Dec 28]. Available from: https://elaws.e-gov.go.jp/document?lawid=401 AC0000000064_20211001_502AC0000000052.

21. Ministry of Health, Labor and Welfare. Social security reform program law [Internet]. Japan: 2016 Apr 1 [cited 2021 Dec 28]. Available from: https://elaws.e-gov.go.jp/document?lawid=425AC0000000112.

22. Kyoto Medical Practitioners Association. "Rehabilitation-related organization council” established by reorganizing 5 group council [Internet]. Japan: 2013 Feb 25 [cited 2021 Dec 28]. Available from: healthnet.jp/wpcontent/themes/main/pdf/medipaper/m164.pdf.

23. Donabedian A. The quality of care: how can it be assessed? JAMA. 1988; 260(12):1743-8.

24. Kotake A. Improve the quality of convalescent rehabilitation wards with outcome assessment. Nursing manager communication. 2009;6(5):105-9.
25. National Convalescent Rehabilitation Ward Liaison Council. Combined process with "quality evaluation" for the evaluation of convalescent rehabilitation ward [Internet]. Japan: 2009 Jul 28 [cited 2021 Dec 28]. Available from: https://mf.jiho.jp/article/p-1300853213602.

26. Watanabe S. Current status and issues of convalescent rehabilitation ward. The Japanese Journal of Rehabilitation Medicine. 2009;46(12): 799-807.

27. Japanese Chronic Medical Association. Request for revision of medical fees in 2010 [Internet]. Japan: 2009 Jul 16 [cited 2021 Dec 28]. Available from: https://jamcf.jp/chairman090716.html.

28. Ishikawa M. To further evolve the convalescent rehabilitation ward. The Japanese Journal of Rehabilitation Medicine. 2016;53(3):190-6.

29. Central Social Insurance Medical Council. Outcome evaluation of convalescent rehabilitation ward, should it be stricter in the next revision? [Internet]. Japan: 2017 Oct 25 [cited 2021 Dec 28]. Available from: gemmed. ghc-j.com/?p=16447.

30. Inpatient Medical Subcommittee of Ministry of Health, Labor and Welfare. FIM evaluation in convalescent rehabilitation ward, implementation of central intravenous nutrition in medical treatment ward, verification of proper performance [Internet]. Japan: 2019 Sep 9 [cited 2021 Dec 28]. Available from: gemmed.ghc-j.com/?p=28526.

31. Central Social Insurance Medical Council. Consider raising the standard value of the convalescent rehabilitation ward 1,3,5, and the rehabilitation performance index [Internet]. Japan: 2019 Dec 6 [cited 2021 Dec 28]. Available from: gemmed.ghc-j.com/?p=31190.

32. Rehabilitation-related Organization Council. Convalescent rehabilitation ward 1. consider making "third-party evaluation" requirements to ensure a systematic and correct evaluation system [Internet]. Japan: 2021 Oct 28 [cited 2021 Dec 28]. Available from: gemmed.ghc-j.com/?p= 43947.

33. Inpatient Medical Subcommittee of Ministry of Health, Labor and Welfare. Considering evaluation of convalescent rehabilitation ward, "providing rehabilitation after discharge" [Internet]. Japan: 2017 Jul 24 [cited 2021 Dec 28]. Available from: gemmed.ghc-j.com/?p=14937.

34. Inpatient Medical Subcommittee of Ministry of Health, Labor and Welfare. Whether the ADL evaluation in the rehabilitation ward is inappropriate, why not consider measures to promote the implementation of cardiac rehabilitation? [Internet]. Japan: 2021 Jul 9 [cited 2021 Dec 28]. Available from: gemmed.ghc-j.com/?p=41469.

35. Ministry of Health and Welfare. Enforcement decree of the act on the guarantee of health rights for disabilities and access to medical access [Internet]. South Korea: 2019 Jul 1 [cited 2021 Dec 28]. Available from: https://www.law.go.kr/LSW/lsInfoP.do?efYd=20190701\&lsiSeq= 206477\#0000.

36. Ministry of Health and Welfare. Enforcement rules of the act on the guarantee of health rights for disabilities and access to medical access [Internet]. South Korea: 2021 Dec 28 [cited 2021 Dec 28]. Available from: https://www.law.go.kr/LSW/lsInfoP.do? efYd=20220121\&lsiS eq $=239925 \# 0000$.

37. Ministry of Health and Welfare. "Providing social services centered on home and local communities" full-scale promotion of community care [Internet]. South Korea: 2018 Mar 13 [cited 2021 Dec 28]. Available from: https://www.mohw.go.kr/react/al/sal0301vw.jsp?PAR_MENU_ID= 04\&MENU_ID=0403\&CONT_SEQ=344177. 
38. Ministry of Health and Welfare. ${ }^{\ulcorner}$Community integrated care in 8 local governments [Internet]. South Korea: 2019 Apr 4 [cited 2021 Dec 28]. Available from: http://www.mohw.go.kr/react/al/sal0301vw.
jsp?PAR_MENU_ID=04\&MENU_ID=0403\&page=3\&CONT_SEQ=34 8925\&SEARCHKEY=TITLE\&SEARCHVALUE=\%ED\%86\%B5\%ED\%9 $5 \% \mathrm{~A} \% \mathrm{~EB} \% 8 \mathrm{~F} \% 8 \mathrm{C} \% \mathrm{~EB} \% \mathrm{~B} 4 \% 84$. 